\title{
Performance of Cooking Aerosol Treatment in China Catering: a Review and Assessment
}

\author{
Qi-Chao Zhao, Chang Chen*, Jun-Tong Zhang, Peng-Ju Hu, \\ Xue-Jing Zhang \\ China National Center for Quality Supervision and Test of Environmental Protection Products, \\ Shijiazhuang, Hebei, 050091, China
}

Received: 25 May 2020

Accepted: 2 August 2020

\begin{abstract}
Cooking aerosol treatment was a significant part of the ventilation system in the commercial kitchen, for reducing the emission of particulate matter (PM) and volatile organic compounds (VOCs) in cities. This study was comprehensively reviewed the research progress, the standards and policy of major global regions and the recent development of purifying methods, which was included: (1) wet method, (2) photolysis oxidation method, (3) physical interception method, (4) electrostatic adsorption method and (5) integrated purifying practice. Based on an extensive test of purifying devices, it analyzed the performance parameters of this method, and introduced the mechanisms, the individual characters, the merits and demerits of these purifying methods. According to the data statistics of test reports, it was found that the integrated purifying devices which was based on the electrostatic adsorption method received considerable attention because it had the high and stable purifying capacity and more straightforward installation. The suggestions and prospects for future researches were finally proposed. This review might be used for inspiration in developing novel technologies for cooking aerosol treatment.
\end{abstract}

Keywords: cooking aerosol, Cooking Oil Fumes (COFs), treatment, purifying method

\section{Introduction}

Cooking aerosol generating from commercial kitchens was one of the most fine particulates contribution in China megacities air environment [1]. It was found that cooking process emitted high concentration of particulate matter (PM), mainly the inhalable particulate matter with aerodynamic diameter

*e-mail: xingyuqifeng@yeah.net of $2.5 \mu \mathrm{m}$ or less $\left(\mathrm{PM}_{2.5}\right)$ [2-3], which can be detrimental to human health, ranging from oxidative DNA damage to respiratory damage caused by exposure and inhalation [4], particularly. Growing evidence shows that the severe effects of PM are related to the size of the particulate. Thus, many countries are paying increasing attention to the emission of fine particulates $[5]$.

By the impact of dietary cultural influences, there were many delicate culinary skills in typical Chinese cuisines, such as stir-frying, deep-frying, quick-frying, crisp-frying, burning and roasting [6], especially in the commercial kitchens, which generate a mass of aerosol, 
Table 1. Typical components of VOCs in 5 inspections.

\begin{tabular}{|c|c|c|c|}
\hline No & Component & $\begin{array}{c}\text { Mean value } \\
\left(\mathrm{mg} \cdot \mathrm{m}^{-3}\right)\end{array}$ & $\begin{array}{c}\mathrm{LOD} \\
\left(\mathrm{mg} \cdot \mathrm{m}^{-3}\right)\end{array}$ \\
\hline 1 & Acetone & 0.40 & 0.01 \\
\hline 2 & Benzene & 0.04 & 0.004 \\
\hline 3 & Methylbenzene & 0.12 & 0.004 \\
\hline 4 & Ethyl benzene & 0.01 & 0.006 \\
\hline 5 & p,m-Xylene & 0.03 & 0.009 \\
\hline 6 & Styrene & 0.02 & 0.004 \\
\hline 7 & o-Xylene & 0.02 & 0.004 \\
\hline 8 & Benzaldehyde & 0.03 & 0.007 \\
\hline
\end{tabular}

including: water vapor, particulate matters, fat ash, oil and grease and others. According to the project of "The study on emission characteristics and pollution control counter measures of Volatile organic compounds (VOCs) and particulate matter in catering industry" in China environment protection public welfare industry research projects 2014 (No. 201409017), the total emission of cooking aerosol from urban areas in China was around 244,600 tons which accounted for 1.59\% of the total emissions of smoke and dust in 2005, and accounted for $9.80 \%$ of the emissions of smoke and dust in residential areas. The total emission of non-methane hydrocarbons (NMHC) was around 477,700 tons, which accounted for $1.59 \%$ of the total VOCs emissions. With the rapid advancement of the urbanization process, the emission source density of cooking aerosol was rapidly raised, the cooking effluents from commercial kitchen cannot be ignored. So the cooking aerosol emissions of commercial kitchens were crucial parameters to set standards or regulations in China [7].

In China, the toughest emission standard of the history would be issued soon, which was the first revision of "Emission standards of oil fume for cooking (GB 18483)" [8] since it was enacted in 2001. The standard was applicable to the emission of oil fume and NMHC from commercial kitchens in catering services. In this study, we selected and counted the typical components of VOCs from 5 inspections of inlet cooking oil fumes (COFs) in Beijing, Shanghai, Guangzhou, Shenzhen, and Chongqing (the serial number of reports: GHB2019HB01032, GHB2018HB00540, GHB2018HB00869, GHB2019HB00158, GHB2019HB00126, respectively) given in Table 1. It was detected according to the China trade standard (code: HJ 734-2014[9]), sampling by Tenax TA tubes, and analyzing by GC/MS method.

The Table 1 shows that the cooking aerosol components are a complex mixure, and actual monitoring proved that the components in VOCs of cooking aerosol caused apparent change based on different cuisines, dishes, materials, seasoning, cooking stages, even the different cookers. For example, the components of VOCs from barbecue were different from those in the other cuisines, which were mainly propylene, 1-butene, n-butane, etc. The nonbarbecue cuisines consisted of high concentration of alcohols, and Western fast-food contained relatively high proportion of aldehydes and ketones[10]. Based on the existing conditions of pollutant monitoring technology, implementation cost and environmental impact assessment, as the monitoring objects, NMHC representing total concentration of VOCs was convenient for the implementation [11].

\section{Results and Discussion}

\section{Bibliometrics and Standards Analysis}

\section{Bibliometrics Analysis}

In this study, we used the data from the database of web of science core collection, which the retrieval method, keywords, timespan, citation index was basic search, "catering or commercial kitchen", from 1999 to 2019, SCI-Expanded, respectively. It contained full record and cited references of 1644 papers. And then, the records were placed in EXCEL and the useless and irrelevant records were deleted, such as missing

Table 2. The number of published periodical articles 1999-2019.

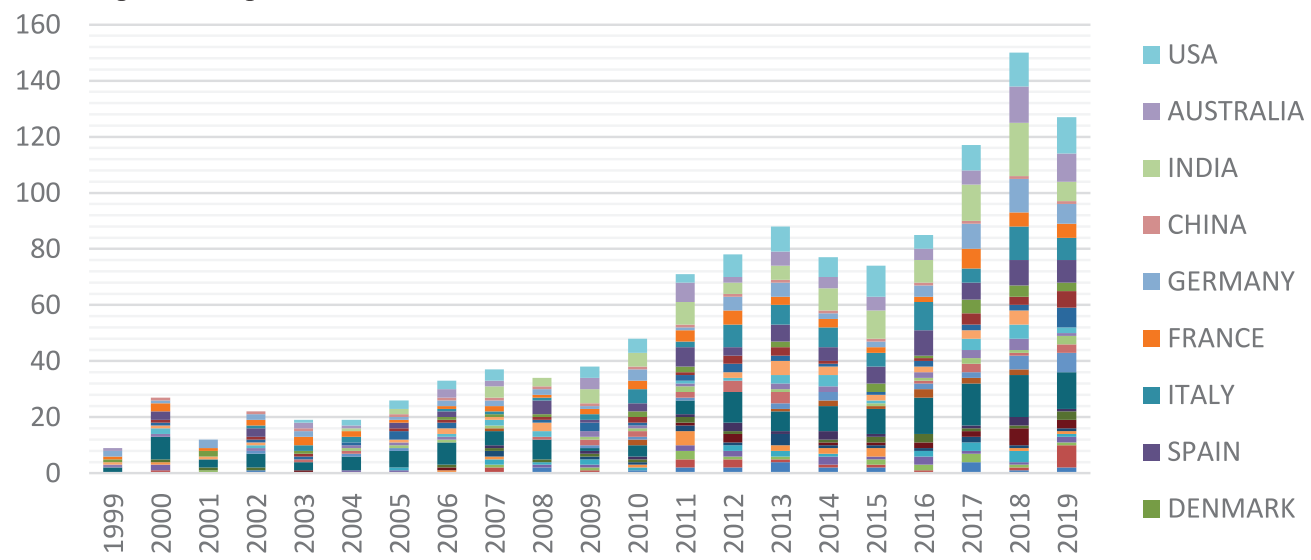


Table 3. Top 20 high-frequency research hotspot in the field of catering.

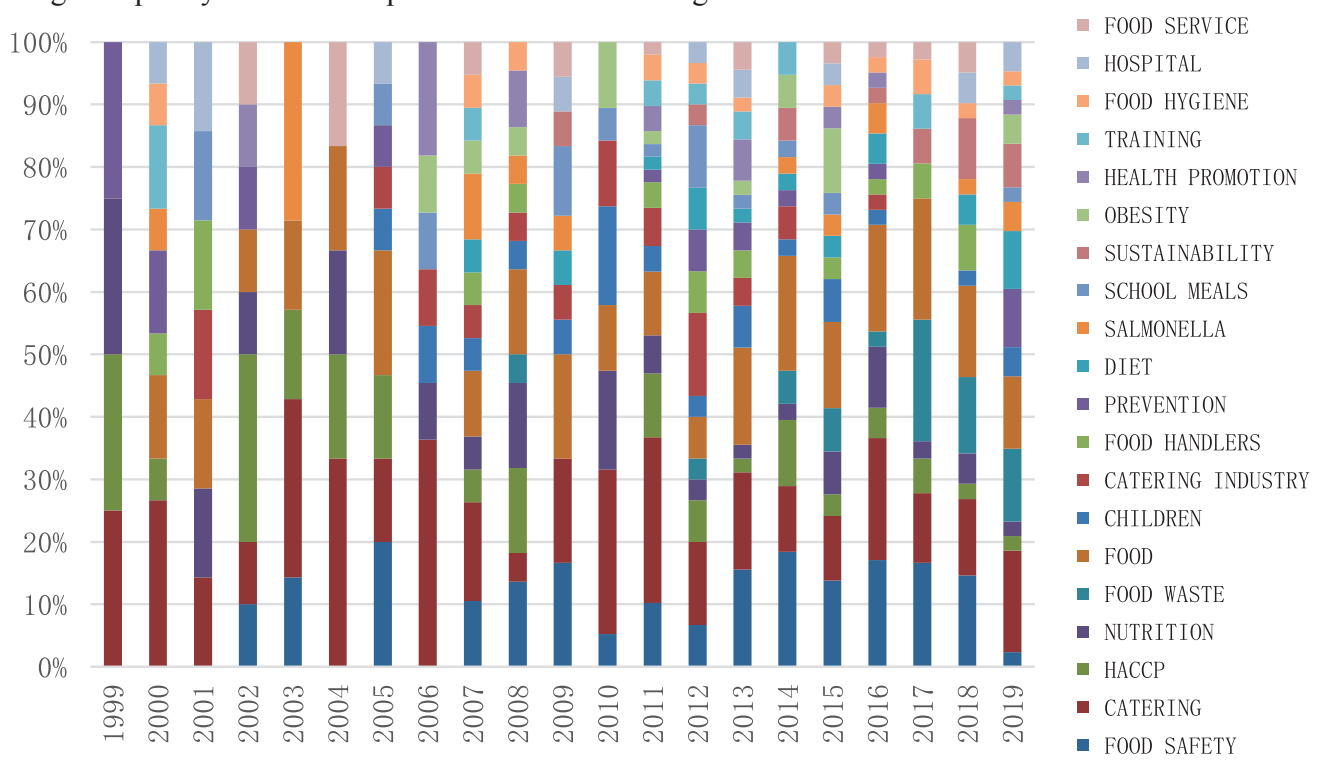

information papers, advertisement, etc. Eventually, we get 1,243 valid records to analyze by Bibexcel, which is a tool for data statistics and relevant analysis. The results showed that the number of published periodical articles was increased, and the public paid increasing attentions on catering, given in Table 2. The table indicated EU and USA played a predominant role in relevant research. The high frequency research hotpots statistics were analyzed, including catering industry, HACCP, food, food safety, food waste, etc. given in Table 3. The table indicates that is gaining increasing concern about different aspects of catering and commercial kitchen. In the separate analysis of word frequency of EU, USA, Japan, China, it shows different perspectives with different diet culture.

\section{Standards Analysis in Main Regions}

With difference of research emphasis and direction, the standards and policies were framed and revised for slightly different aspect. In this study, some standards and policies in main areas were listed and illustrated.

a) In Europe, the standard series of equipment for commercial kitchens (EN 16282:2017) was approved by The European Committee for Standardization (CEN) on 11 May 2017. This European standard is applicable to ventilation systems in commercial kitchens [12], and also specifies commercial kitchen ventilation hoods [13], ventilation ceilings [14], air inlets and outlets [15], air duct [16], aerosol separators [17], fixed fire suppression systems [18], and treatment of cooking fumes [19]. The aerosol treatments were specified, but there is no purifying rate and emission limit. The methods of determination were cited EN 779:2012 [20] or with the aid of a monitoring device.

b) In USA, the standard-setters were focused on safety and fire prevention by setting equipment requirements to guide proprietors, but not specifying emission standards. For example, NFPA 96:2008 [21], UL 710:2009 [22], and UL 1046:2010 [23] specified general requirements, and mentioned grease removal devices. However, it cited a method for grease particle capture (ASTM F 2519:2015)[24] but the emission limit or purifying rate of grease removal.

c) In Japan, the government did not enact standards or policies for catering effluent emission. But the public was push through a voluntary certification system for commercial kitchen grease removal equipment by Japan Food Service Equipment Association (JFEA). The performance of grease removal needed testing by JFEA group standard (JFEA 001-2012), the purifying rate of professional grease removal was needed to exceed $90 \%$, and the others needed to exceed $75 \%$.

d) In China, two standards were implemented from 2001, including compulsory state standard for emission of catering cooking fumes [7] and trade standard of catering cooking fume treatment equipment [25]. And then, another trade standard (HJ 554-2010) [26] was implemented from 2010, which is included not only the general requirements of cooking fume treatment, cooking wastewater treatment, cooking solid waste treatment, noise, and vibration, but also basic design requirements for ventilation. These standards, specified sampling and test methods for cooking fumes and $\mathrm{NMHC}$, and put forward the requirements for the performance of cooking fume treatment, including purifying rate of $\operatorname{COFs}\left(\eta_{C O F s}\right)$, emission limit, pressure drop, and air leakage, etc. Besides, local standards in different province and regions were convenient for law enforcement implementation. Meanwhile, voluntary certification system was provided, evaluating by group standards.

Above all, people focus on different fields of catering, and it was reflected in policy-making, research density and direction, because it had notably diversity of diet habits in different country, given in Table 4 below. 
Table 4. Different fields of catering in main regions.

\begin{tabular}{|c|c|c|c|}
\hline Region & Standards & $\begin{array}{c}\text { Number of published periodical articles } \\
\text { (cite: web of science) }\end{array}$ & $\begin{array}{c}\text { High-frequency Research } \\
\text { hotspot }\end{array}$ \\
\hline \multirow{2}{*}{ EU } & $\begin{array}{c}\text { EN 16282:2017 } \\
\text { EN 799:2012 }\end{array}$ & 756 & Food \& \\
FSA & $\begin{array}{c}\text { NFPA 96:2008 } \\
\text { UL 710:2009 } \\
\text { UL 1046:2010 }\end{array}$ & 99 & Health \\
\hline Japan & $\begin{array}{c}\text { JFEA 001-2012 } \\
\text { Group standards }\end{array}$ & \multirow{2}{*}{$\begin{array}{c}\text { Food waste } \\
\text { China }\end{array}$} & $\begin{array}{c}\text { GB 18483(Revising) } \\
\text { HJ 554-2010 } \\
\text { HJ/T 62-2001 }\end{array}$
\end{tabular}

\section{Pollution Control in Catering of China}

The pollution of catering was divided into aerosol pollution, wastewater pollution, solid waste pollution, and physical pollution. In the present study, with the actual test and monitoring in China, it was shown the existing treatment technology was relatively easy to control wastewater and solid waste in catering, because of good biodegradability [27-28]. And the physical pollution (including noise, vibration and heat, etc.) was mainly generated from treatment equipment and ventilation, it could be handled by good design and proper construction. Therefore, the critical matter in catering pollution, such as primary organic aerosols (POA) and secondary organic aerosol (SOA) [29], were the methods to control aerosol pollution, because massive VOCs and PM have the potential to be released during the cooking process [30].

For this study, 2,310 tests were conducted to the performances of cooking aerosol treatment equipment from 2015 to 2019, which included purifying rate of $\operatorname{COFs}\left(\eta_{C O F s}\right)$, pressure drop, air leakage, etc. According to the test method of standard (GB 18483 [7] and $\mathrm{HJ} / \mathrm{T} 62$ [25]), The COFs was collected in sampling tube by sampling system (Laoying3012H Automatic Stack Dust Sampler /Flue Gas Analyzer), extraction by tetrachloroethlyene, and then tested the oil content by infrared spectrometry method. In the test, the inlet of concentration of COFs was set up $10 \mathrm{mg} / \mathrm{m}^{3}$, and the concentration variation rate was remained within $5 \%$. The concentration of COFs was obtained through calculating the oil content and sampling volume. The $\eta_{\text {COFs }}$ and pressure drop of purifying devices were obtained through testing and calculating its concentration of COFs and total pressure differential in the front and back of air duct, as shown in Fig. 1.

622 test reports of China National Center for Quality Supervision and Test of Environmental Protection Products were presented in actual projects. Based on these result data in tests and reports, several aerosol treatment methods of catering were specified, and summarized parameters of cooking aerosol treatment equipment with single purifying method (SPM) and integrated purifying method (IPM) were given in Table 5.

\section{Cooking Aerosol Treatment Methods}

a) Wet method

It was adsorption methods which was relied on water curtain or spray (tap water or chemical solvent) to capture cooking aerosol [31-32]. In this scope, it was divided into water spray treatment and impinging stream treatment, the significant difference was the liquid state during gas-liquid inertia collision. The water spray treatment generated water curtain or water spray

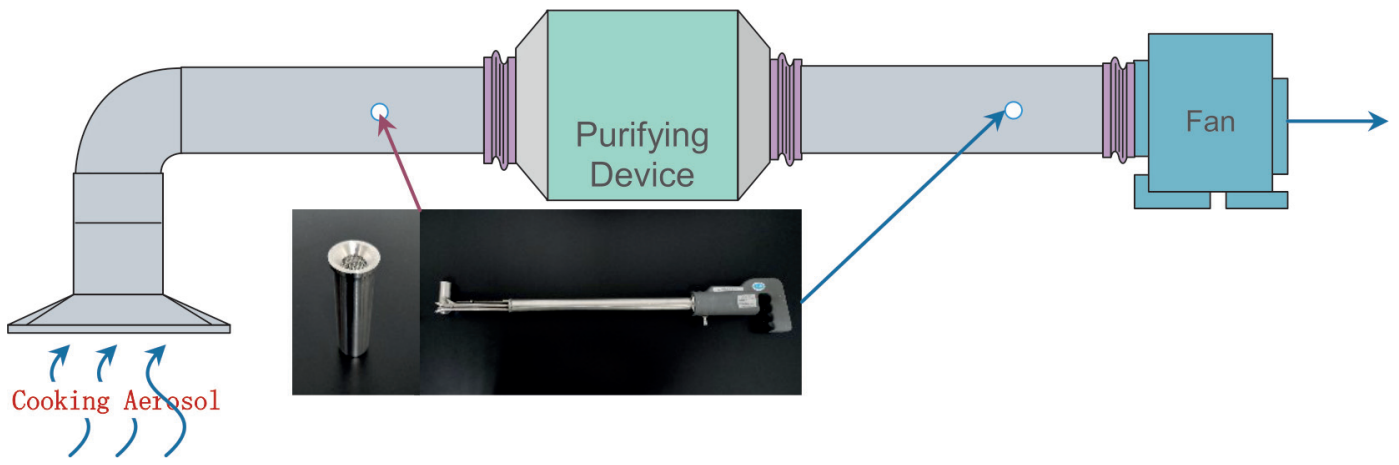

Fig. 1. The sketch of test system of purifying device. 


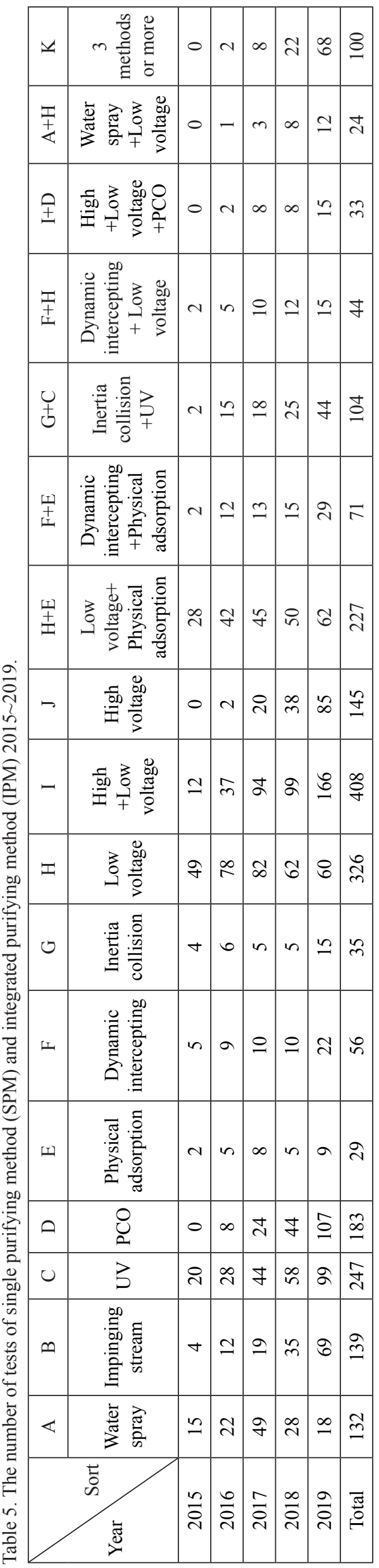

with large droplets, and the impinging stream treatment generated high-speed spray with smaller droplets to capture and adsorb the aerosol [33-34]. The liquid state had great influence on purifying rate of COFs $\left(\eta_{\mathrm{COF}}\right)$, tests were conducted of two kinds of devices with single purifying method. The test results indicated the average $\eta_{\text {COFs }}$ of impinging stream treatment $(90.2 \%)$ is much higher than water spray treatment $(73.8 \%)$.

With this method, extra oily wastewater was produced that resulted in additional operation and maintenance cost, and moisture content of airflow could be increased. However, a fraction of VOCs could be adsorbed into the liquid, and temperatures would be reduced. In China, the overwhelming majority of wet method purifying unit were designed and installed in hood or next to hood, which would greatly reduce the fire risk by cooking oil fumes sedimentation in air duct.

b) Photolysis oxidation method

It was based on the effect of short-wave UV radiation and the chemical reactions of the "active oxygen" (including $\mathrm{O}^{*}, \mathrm{OH}^{*}, \mathrm{H}^{*}, \mathrm{O}_{3}$ ) generated from the oxygen in the airflow and water molecules with the organic particles. The reactions residue from oxidation was mainly water, carbon dioxide, and fat ash. In practice, it was divided into UV device and Photocatalytic oxidation (PCO) device, which the latter had higher efficiency to generate "active oxygen" by aid of catalyst. This method could not only purify organic particles, but also disinfect and sterilize [35]. However, it should avoid droplets or large-size particles (including PM, oil, grease, etc) damaging UV lamp, so it always installed guide plate or other purifying unit before UV and photo-catalytic oxidation unit in China. With the SPM and general guide plate, the average $\eta_{\text {COFs }}$ of UV device and PCO device was $78.2 \%$ and $88.7 \%$, respectively.

It should be noted that this methods had negative impact by UV radiation and ozone emission, even low concentration [36]. This was due to the strong oxidation of "active oxygen" and UV radiation, which could destroy the DNA molecular structure. However, there was no safety requirement for leakage of UV radiation and ozone emission limit in standard system of China catering, which it was ensured the eyes and skin not to expose to UV radiation or inhale ozone. In EN 16282-8:2017 of EU standard, it was stipulated that the effective radiation strength $\left(\mathrm{E}_{\text {eff }}\right)$ shall not exceed $0.5 \mathrm{~mW} / \mathrm{m}^{2}$ measured at a distance of $10 \mathrm{~cm}$ below the device. And it was also stipulated the concentration of ozone in the exhaust air without kitchen operation shall not exceed 10ppm measured at the outlet of the building.

c) Physical intercepting method

It was a method which was based on physical adsorption or physical interception. In China, it was divided into physical adsorption method, dynamic interception method, and inertia collision, generally. In practice, the physical adsorption method was the simplest method to purification, and it was included 
Table 6. The characteristics of each SPM.

\begin{tabular}{|c|c|c|c|c|c|}
\hline \multicolumn{2}{|c|}{ Sort Characteristic } & $\begin{array}{c}\text { Average } \eta_{C O F s}, \\
\%\end{array}$ & $\begin{array}{l}\text { Pressure } \\
\text { drop, Pa }\end{array}$ & Advantages & Disadvantages \\
\hline \multirow{2}{*}{ Wet method } & Water spray & 73.8 & 125 & \multirow{2}{*}{$\begin{array}{c}\text { Fire prevention } \\
\text { Reducing aerosol temperature } \\
\text { Fraction of VOCs removal } \\
\text { Easy to clean }\end{array}$} & $\begin{array}{l}\text { Low } \eta_{C O F s} ; \\
\text { Wastewater }\end{array}$ \\
\hline & $\begin{array}{l}\text { Impinging } \\
\text { stream }\end{array}$ & 90.2 & 133 & & $\begin{array}{l}\text { Large area occupied } \\
\text { Wastewater }\end{array}$ \\
\hline \multirow{2}{*}{$\begin{array}{l}\text { Photolysis } \\
\text { oxidation }\end{array}$} & UV & 78.2 & 104 & \multirow{2}{*}{$\begin{array}{c}\text { VOCs removal } \\
\text { Residues pollution-free } \\
\text { Disinfection }\end{array}$} & High operation costs \\
\hline & $\mathrm{PCO}$ & 88.7 & 110 & & $\begin{array}{l}\mathrm{UV} \text { radiation and } \mathrm{O}_{3} \text { emission } \\
\text { Low durability }\end{array}$ \\
\hline \multirow{3}{*}{$\begin{array}{l}\text { Physical } \\
\text { intercepting }\end{array}$} & $\begin{array}{l}\text { Physical } \\
\text { adsorption }\end{array}$ & 93.0 & 228 & $\begin{array}{l}\text { VOCs removal } \\
\text { Simple and Stable }\end{array}$ & $\begin{array}{l}\text { High pressure drop } \\
\text { Hard recycling }\end{array}$ \\
\hline & $\begin{array}{l}\text { Dynamic } \\
\text { intercepting }\end{array}$ & 93.6 & 155 & $\begin{array}{l}\text { High } \eta_{C O F s} ; \\
\text { Oil recoverable }\end{array}$ & $\begin{array}{c}\text { Low purifying rate for VOCs } \\
\text { Noise }\end{array}$ \\
\hline & $\begin{array}{l}\text { Inertia } \\
\text { collision }\end{array}$ & 87.7 & 180 & $\begin{array}{l}\text { Elegant appearance } \\
\text { Oil recoverable }\end{array}$ & $\begin{array}{c}\text { Low purifying rate for VOCs } \\
\text { High pressure drop; }\end{array}$ \\
\hline \multirow{3}{*}{$\begin{array}{c}\text { Electrostatic } \\
\text { adsorption }\end{array}$} & Low voltage & 82.9 & 123 & Convenient to use & \multirow{3}{*}{$\begin{array}{l}\text { High energy consumption } \\
\text { High maintenance costs } \\
\text { High cleaning costs }\end{array}$} \\
\hline & $\begin{array}{l}\text { High-Low } \\
\text { voltage }\end{array}$ & 92.2 & 126 & \multirow{2}{*}{$\begin{array}{c}\text { High } \eta_{\text {COFs }} ; \\
\text { Low pressure drop } \\
\text { Fraction of VOCs removal }\end{array}$} & \\
\hline & High voltage & 96.2 & 126 & & \\
\hline
\end{tabular}

activated carbon device, zeolite or carbon molecular sieve [37], and grease filter of nonwovens or other new material. These devices had high efficiency of adsorption and interception, but in the meantime, high pressure drop and hard recycling should to be noted.

Because of the characteristics of small pore diameter and high specific surface area, it was a powerful approach to adsorb PM and VOCs by activated carbon device and zeolite molecular sieve [38]. However, it was easily blocked by high concentration of PM and high humidity for the same reason [39-40]. So this kind of devices was installed in the last of ventilation as advance treatment, usually. Dynamic interception and inertia collision separators were always installed on the hood as a separating plate or guide plate, which would get excellent performance with appropriate design. The PM of COFs was effective separated and gathered by kinetic force of high-speed rotating blades or guide plate with special section design. The methods of dynamic interception method and inertia collision were more effective for removal of droplets and largesize particles, usually as pre-treatment in whole system, but it could be found in using alone which it contained single purifying mode in recent years. Based on result of test, the average $\eta_{C O F s}$ of physical adsorption device, dynamic interception separator, and inertia collision guide plate, in turn, was $93.0 \%, 93.6 \%$ and $87.7 \%$ with the SPM.

d) Electrostatic adsorption method

This method was widely used in industrial dust removal (such as electrostatic precipitator), which was used to clean the effluents by using high voltage to ionize air molecules and having followed by both negative and positive charged collector plates to remove charged particles from the airflow. It was proven that this method had effective reduction in cooking aerosol, not only PM adsorption (even the submicron particles), but also had effect on VOCs removal [41-42], because the relative large separating force (mainly electrostatic force) acted on particles directly. Besides, the high voltage formed plasma with active oxygen and ozone by ionized air and water molecules, which could synergistic be improved purifying capacity.

In practice, this method was gradually applied to mainstream use, because it had the characteristics of high captured capacity, low airflow resistance, and easy to clean. With the development of electrostatic adsorption method, it was divided into relative lowvoltage device (6,000-12,000 volt), high-low-voltage device and high-voltage device, which the voltage of latter could be reached 13,000 volt or more. The prerequisite was an appropriate design, which included enough specific collection area (SCA), enough lengthwidth ratio, suitable airflow velocity and migration velocity, etc. In recent year, the usage of single lowvoltage devices was eliminated gradually because it was failed to meet the requirements of standards (the average $\eta_{\text {COFs }}$ is $82.9 \%$ ). Instead, the use of high-lowvoltage devices or high-voltage devices (the average $\eta_{\text {COFs }}$ is $92.2 \%$ and $96.2 \%$ ) which were designed for multiple electrostatic fields and distributed control with several power control were increased significantly.

e) Integrated purifying method

There are obvious advantages and disadvantages of single purifying method (given in Table 6). It had an effect on improving $\eta_{\mathrm{COFS}}$ and reducing operation cost 
Table 7. The purifying rate and number of tests of different purifying method device.

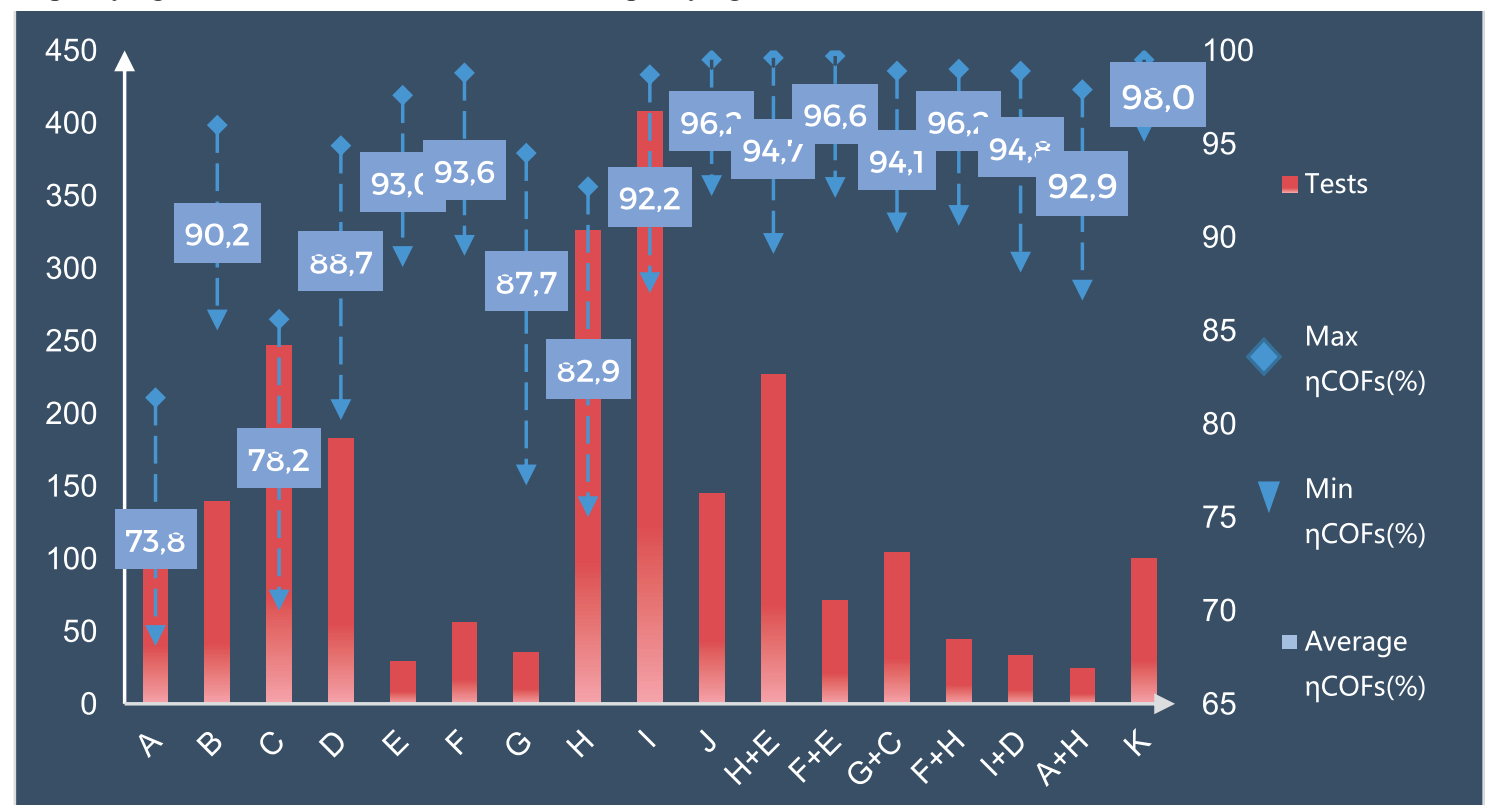

by learning from each other's strong points to close the gap. In China, the most common integrated purifying devices were low-voltage electrostatic \& activated carbon adsorption devices, dynamic interception separator \& grease filter devices, inertia collision guide plate \& UV devices, dynamic interception separator \& low-voltage electrostatic devices, high-low-voltage electrostatic \& PCO devices, water spray \& low-voltage electrostatic devices and integrated device of 3 methods or more. Based on test results, the average was $94.7 \%$, $96.6 \%, 94.1 \%, 96.2 \%, 94.8 \%, 92.9 \%$, and $98.0 \%$, respectively, given in Table 7 .

With the actual survey and test in most regions of China, in view of complex technologies or hard operation, other purifying methods were barely used in China catering and commercial kitchens, such as microbiological treatment, regeneration catalytic oxidizer (RCO), etc.
Reports Analysis

In the study, 622 test reports of cooking aerosol removal devices was conducted in project acceptance inspection or type test. With the number and kinds of devices, the results showed the number of reports was increased year by year, and compared with other methods, the increasing trend of IPM devices were most obvious.

In the actual projects, the SPM devices which had relative low pressure drop and high average $\eta_{\text {COFs }}$ (close or beyond 90\%), could be used alone (given in Table 8). That trend was consistent with the requirement of new state standard for purifying rate. According to the test results (Table 7), the $\eta_{\text {COFs }}$ of SPM show widely floating range, but IPM were offered positive offset for purifying stabilization. The impact of different concentration of COFs in different methods was also

Table 8. Pressure drop and the average $\eta_{C O F s}$ of SPM.

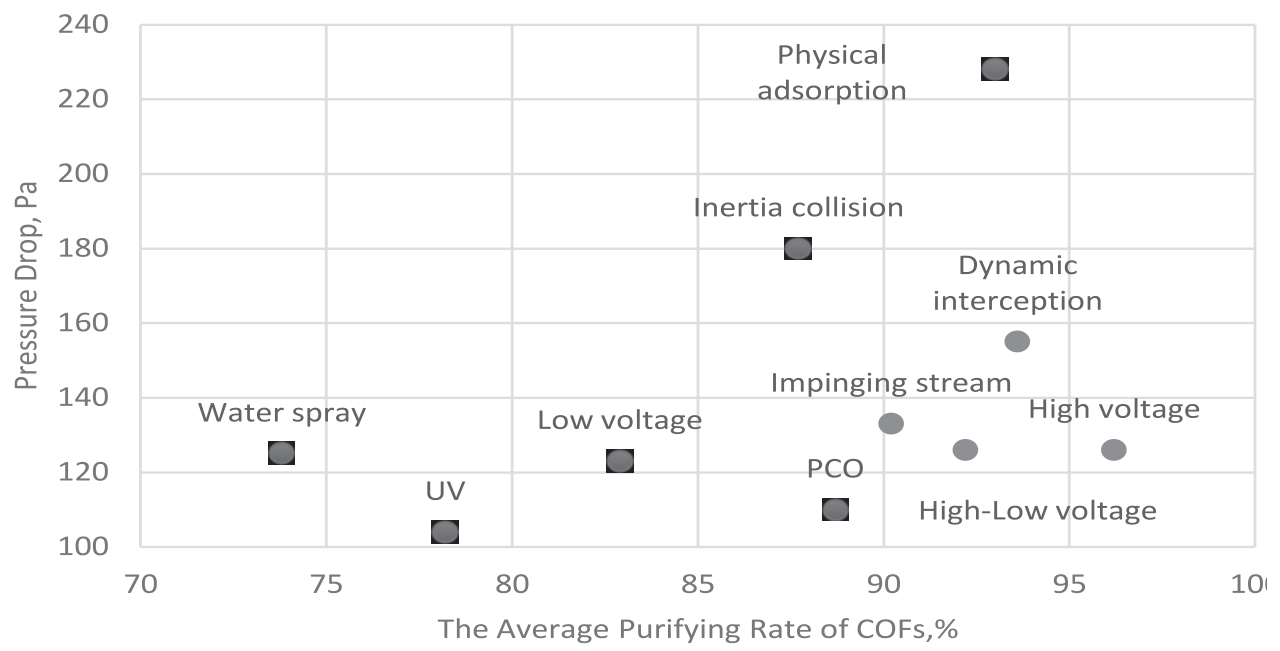


Table 9. Effects of concentration of COFs on the $\eta_{C O F S}$ of different purifying methods (Airflow was $12000 \mathrm{~m}^{3} / \mathrm{h}$ ): a) Impinging stream device; b) High-voltage electrostatic device; c) Comparing of UV device (C) and inertia collision guide plate\&UV devices (G+C); d) Comparing of low-voltage electrostatic devices $(\mathrm{H})$ and dynamic interception separator\&low-voltage electrostatic devices $(\mathrm{F}+\mathrm{H})$.

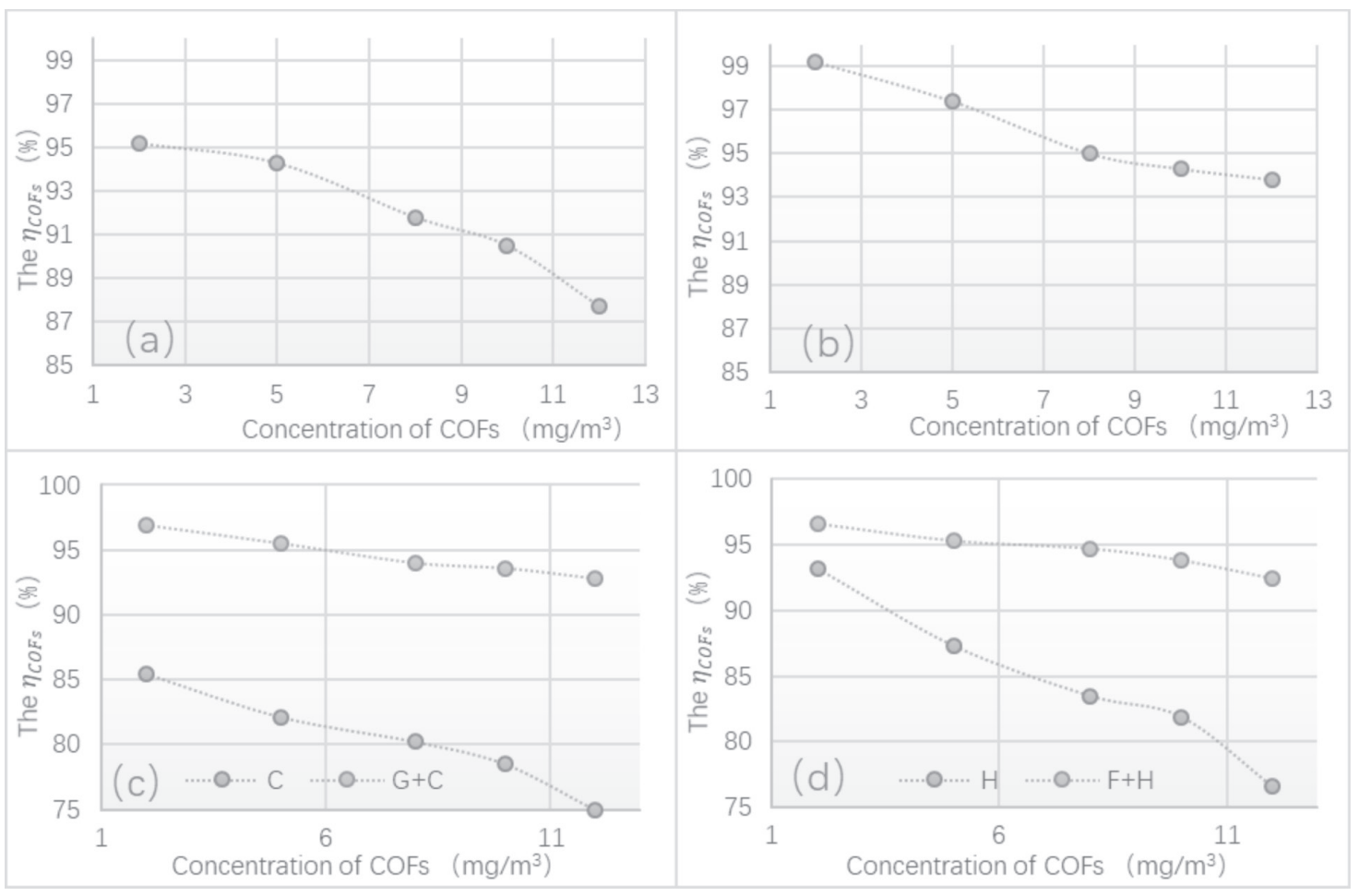

investigated. The results showed that the $\eta_{\mathrm{COFS}}$ of SPM was affected by concentration of COFs significantly. The IPM device could resist concentration change comparing with the corresponding SPM device, as seen in Table 9. So the IPM devices became most popular, especially based on electrostatic adsorption, because it could provide significant improvement of $\eta_{C O F s}$ and could remove parts of VOCs at the same time.

For the reports, the main test areas were concentrated in greatest vital development areas in China (including: capital circle, Pearl River and Yangtze River deltas region), such as Guangdong prov., Beijing, Shandong prov. and Jiangsu province. It was also consistent with the total number of manufacturers who had obtained the certification of Environmental Products (CEP) by statistics of China Association of Environmental Protection Industry (CAEPI) in a three-year certification period (2016-2018), as Fig. 2. Among these main region, there was a quality gap between devices of Shandong and others, initially. However, with stricter requirements for purifying rate and emission limit, it had gradually catch up with its rivals. The $\eta_{C O F s}$ of overall devices was improved year by year, and the test of emission of NMHC and PM was increased from 2018.

\section{Suggestion}

With the comparison of the different regions standards, it was found that China standards paid more attention to purifying device in commercial kitchen, which enacted the standard for emission limit of
COFs, PM and NMHC, and the separate standards for performance assessment of cooking aerosol treatment equipment. Also, the new state emission standard of COFs would be implemented in 2020. Besides, the other requirements of commercial kitchen equipment were to some extent ignored, such as hygiene, cleaning, maintenance, fire control and durability, etc. These requirements should be complemented in relevant standards or design specifications for commercial kitchen equipment. Based on statistics of the number

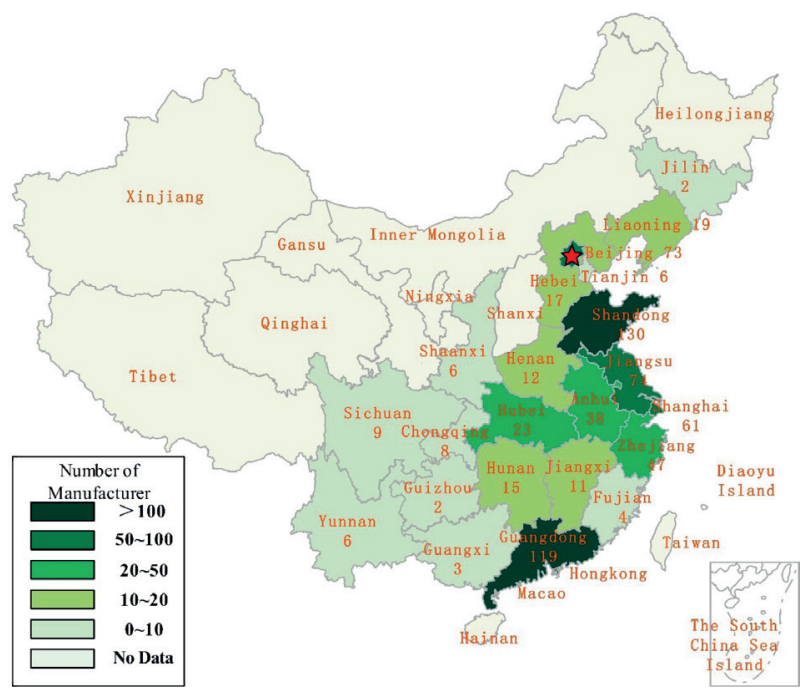

Fig. 2. The number of manufacturers of Commercial kitchen purifying device in China. 
and topic of published periodical articles, there was less concern to the performance for catering effluents treatment (especially cooking aerosol treatment) in EU, USA and Japan, perhaps because of different dietary habit or other reasons, it was restricted the development and promotion in this field. However, the emission of cooking aerosol has claimed an ever-growing share of the total emission of VOCs, so the demand for cooking aerosol purifying device was increased year by year in China.

However, notwithstanding the effort in China, there was no breakthrough for the purifying methods. The main design was focused on how to intercept PM and VOCs in COFs through chemical, physical or electrostatic adsorption, but recycle. And it was just integrating these different methods to a multistage device, or relied on improvement of manufacturing process and installation. While purifying process, it was needed to consume huge resources and take up plenty of space for air ducts and equipments, which would be not only added environment burden, but also affected aesthetics. The results of test and survey show that it would not eliminate secondary pollution completely, and needed replacing filter materials or cleaning and maintenance by qualified technical personnel.

The $\eta_{C O F s}$ of wet method was proportional to the relative velocity between $\mathrm{COFs}$ and droplets, and inversely proportional to the diameter of droplets. In a real application, the impinging stream treatment was organized around these two points to design for improving $\eta_{\mathrm{COF} \text { s }}$. But the smaller droplet was easier to move with airflow and slow the relative velocity down, so not the smaller diameter of droplet was the better. For improving $\eta_{C O F s}$, it should do more research on optimal diameter of droplet which had more effect to remove COFs. Besides, wet method devices were needed to change water and purificant per 3-5 days for maintain its purifying capacity.

For photolysis oxidation device, service life was affected by operation condition considerably, as it was unable to remove large particles. For this reason, it had to clean the UV lamp per 3 months even though the system has front purifying units. Above all, it was needed enough distance and time to ensure sufficient reaction of "active oxygen" and COFs. The devices were suited as advance purification in whole system, but the risk of UV radiation and ozone leakage should be noted.

The purifying principle of physical adsorption devices was simple and effective, the most important problems were high resistance, low durability and hard recycling. It was hardly a major purifying process in system, as there was a need to change activated carbon or filters about 3-6 months. The dynamic interception separator and inertia collision guide plate could intercept most COFs and gather the oil and fat before the COFs entered into the air duct, which was conductive to reduce oil sedimentation and the fire risk. However, it was unable to remove VOCs and there was obvious noise and pressure drop in dynamic interception separator and guide plate, respectively, so it was better to combine with other purifying unit in the back to obtain optimal purifying capacity.

As a main stream of purifying method in China catering, the electrostatic adsorption device had capacity to remove PM and VOCs, simultaneously, especially the high-voltage device had enough high $\eta_{C O F s}$ alone by improving field intensity and corona current which was conductive to charge PM and ionize air, and it was unshackled from the airflow direction in electric field. However, the $\eta_{\text {COFs }}$ was remarkable dropped causing by oil sedimentation in electric field, and it had to clean with alkali solution per 3 months, so the field cleaning was main operation cost. And the high voltage power supply often caused malfunction and fire. Hence, the durability and reliability of this devices were needed to be improved.

In China, there was some progress in purifying method upgrade. For example, a) a wet method has efficient purifying improvement for VOCs and PM, by combining with surfactant and oxidant [43]. b) The modified nano-structure catalyst was used in PCO device to improve photoreactivity [44-45]. c) The hydrophobic modified activated carbon [46] for complex cooking aerosol removal had obvious improvement. d) A new design for a rotated electric field was improved SCA which had function of self-cleaning. These devices had been put to use in some commercial kitchen. The Chinese manufacturers were devoted to design a closed system which has all function of air conditioning, ventilation, purification and recycle function, etc.

From test reports and actual projects, it was found that the and other performance of newly-installed devices were able to fulfill the design requirement, basically, but with the increase in service time, all of performances of purifying device would gradually descended, even it had normal cleaning and maintenance. Therefore, the requirement for purifying stabilization should be proposed, and it was needed to establish test methods for its durability and reliability, and then it could provide a feasible guidance for performance predictions and selection suggestions with the statistic and analysis of the performance of purifying device.

\section{Conclusions}

This study shows the significance of cooking aerosol treatment in catering. Through bibliometrics and standard comparison, it was analyzed and summarized the difference of research direction and policy-making. Based on the data from 2,310 tests and 622 reports, the mechanisms, the technical characters, the advantages and disadvantages of these purifying methods were elaborative discussed. And it was found that the development trends of the purifying device was for integrated purifying method which was mainly 
based on electrostatic adsorption method in China. The study proposed the possible research suggestions for each purifying method in the end. This review was an inspiration in the development of novel purifying methods for cooking aerosol treatment or commercial kitchen ventilation system.

\section{Acknowledgements}

The authors appreciate the financial support by Local Standard Formulation and Amendment Plan of Hebei Province (No. GY201693), and Science and Technology Plan of Hebei Administration for Market Regulation (No. 2016ZD06), the fundamental research funds for the China National Center for Quality Supervision and Test of Environmental Protection Products (No. 201503, 201606, 201702, 201804, 201903).

\section{References}

1. Beijing Municipal Ecology and Environment Bureau. Beijing ecology and environment statement 2018, 2019 [In Chinese].

2. SUN C.Y., BAI H.H., CHEN X., ZHAI Y.F., GAO Q.T., HE W.Q., NIE L.,SHI A.J., LI G.A. Emission Characteristics of Catering Industry in Beijing,. Environment Science: 1-8[2020-04-04]. https://doi.org/10.13227/j.hjkx.201911076. 2020 [In Chinese]

3. ROBINSON E.S., GU P.S., YE Q., LI H.Z., SHAH R.U., APTE J.S., ROBINSON A.L., PRESTO A.A. Restaurant Impacts on Outdoor Air Quality: Elevated Organic Aerosol Mass from Restaurant Cooking with Neighborhood-Scale Plume Extents. Environmental science \& technology, 52 (16), 2018.

4. ZHAI S.R, ALBRITTON D. Airborne particulates from cooking oils: Emission test and analysis on chemical and health implications. J. Sustainable Cities and Society,52, 2020.

5. KIM K.H., KABIR E., KABIR S. A review on the human health impact of airborne particulate matter. Environment International, 74, 136-143. doi:10.1016/j.envint.2014.10.005, 2015.

6. LI A.G., ZHAO Y.J., JIANG D.H., HOU X.T. Measurement of temperature, relative humidity, concentration distribution and flow field in four typical Chinese commercial kitchens. Building and Environment, $56,2012$.

7. BI X.H., DAI Q.L., WU J.H., ZHANG Q., ZHANG W.H., LUO R.X., CHENG Y., ZHANG J.Y., WANG L., YU Z.J., ZHANG Y.F., TIAN Y.Z. Characteristics of the main primary source profiles of particulate matter across China from 1987 to 2017. Atmospheric Chemistry and Physics. 19. 3223-3243. 10.5194/acp-19-3223-2019, 2019.

8. GB 18483-2001 Emission standards of oil fume for cooking [In Chinese].

9. HJ 743-2014 Stationary source emission Determination of volatile organic compounds Sorbent adsorption and thermal desorption gas chromatography mass spectrometry method [In Chinese].

10. CUI T., CHENG J.C., HE W.Q., REN P.F., NIE L., XU D.Y., PAN T. Emission characteristics of VOCs from typical restaurants in Beijing . J.Environment Science, $\mathbf{3 6}$ (5), 1523-, 2015 [In Chinese].

11. Compilation illustration for Emission standards of oil fume for cooking [In Chinese].

12. EN 16282-1:2017 Equipment for commercial kitchenscomponents for ventilation in commercial kitchens-Part 1 : General requuirements including calculation method.

13. EN 16282-2:2017 Equipment for commercial kitchenscomponents for ventilation in commercial kitchens-Part 2: Kitchen ventilation hoods-Design and safety requirements.

14. EN 16282-3:2017 Equipment for commercial kitchenscomponents for ventilation in commercial kitchensPart 3: Kitchen ventilation ceilings-Design and safety requirements.

15. EN 16282-4:2017 Equipment for commercial kitchenscomponents for ventilation in commercial kitchens-Part 4 Air inlets and outlets-Design and safety requirements.

16. EN 16282-5:2017 Equipment for commercial kitchenscomponents for ventilation in commercial kitchens-Part 5: Air duct-Design and dimensioning.

17. EN 16282-6:2017 Equipment for commercial kitchenscomponents for ventilation in commercial kitchens-Part 6 : Aerosol separators-Design and safety requirements.

18. EN 16282-7:2017 Equipment for commercial kitchenscomponents for ventilation in commercial kitchens-Part 7: Instalation and use of fixed fire suppression systems.

19. EN 16282-8:2017 Equipment for commercial kitchenscomponents for ventilation in commercial kitchensPart 8: Installations for treatment of cooking aerosolRequirements and testing.

20. EN 799:2012 Particulate air filters for general ventilationDetermination of the filtration performance.

21. NFPA 96:2008 Standard for ventilation control and fire protection of commercial cooking operations.

22. UL 710:2009 Standard for exhaust hoods for commercial cooking equipment.

23. UL 1046:2010 Standard for grease filters for exhaust ducts.

24. ASTM F2519:2005 Standard Test Method for Grease Particle Capture Efficiency of Commercial Kitchen Filters and Extractors.

25. HJ/T 62-2001 Test regulation for cooking fume control equipment [In Chinese]

26. HJ 554-2010 Specification for environmental protection of catering trade. [In Chinese]

27. KLIOPOVA I., STANIŠKIS J.K., STUNŽĖNAS E., JUROVICKAJA E. Bio-nutrient recycling with a novel integrated biodegradable waste management system for catering companies. Journal of Cleaner Production, doi: https://doi.org/10.1016/j.jclepro.2018.10.185, 2018.

28. TOLVANEN O.K., HÄNNINEN K.I. Mechanicalbiological waste treatment and the associated occupational hygiene in Finland. Waste Management, 26 (10), 1119, 2016.

29. KLEINDIENST T.E., MOHAMMED JAOUI, LEWANDOWSKI M., OFFENBERG J.H., LEWIS C.W., PRAKASH V. BHAVE, EDNEY E.O. Estimates of the contributions of biogenic and anthropogenic hydrocarbons to secondary organic aerosol at a southeastern US location. Atmospheric environment, 41 (37), 8288, 2007.

30. HONGLI WANG, ZHIYUAN XIANG, LINA WANG, SHENGAO JING, SHENGRONG LOU, SHIKANG TAO, JING LIU, MINGZHOU YU, LI LI, LI LIN, YING CHEN, ALFRED WIEDENSOHLER, CHANGHONG CHEN Emissions of volatile organic compounds (VOCs) from cooking and their speciation: A case study for 
Shanghai with implications for China. Science of The Total Environment, 621 (1), 33, 2017.

31. TESSUM M.W., RAYNOR P.C Effects of Spray Surfactant and Particle Charge on Respirable Coal Dust Capture. Safety and Health at Work, 8 (3), 2017.

32. CHENG H.H., HSIEH C.C. Integration of chemical scrubber with sodium hypochlorite and surfactant for removal of hydrocarbons in cooking oil fume. Journal of hazardous materials, 182 (1-3), 2010.

33. CORNO A.D., MORANDI S., PAROZZI F., ARANEO L., CASELLA F. Experiments on aerosol removal by highpressure water spray. J. Nuclear Engineering and Design, 311 (JAN.), 28, 2017.

34. KALTENBACH C., LAURIEN E. CFD Simulation of aerosol particle removal by water spray in the model containment THAI. J. Journal of Aerosol Science, 120, 62, 2018.

35. CARRA I., FERNANDEZ L.J., AUTIN O., BOLTON J.R., JARVIS P. Disinfection by-product formation during UV/Chlorine treatment of pesticides in a novel UV-LED reactor at $285 \mathrm{~nm}$ and the mitigation impact of GAC treatment. The Science of the total environment, 712, 136413, 2020.

36. EVGENIOS AGATHOKLEOUS, REGINA G. BELZ, VICENT CALATAYUD, ALESSANDRA DE MARCO, YASUTOMO HOSHIKA, MITSUTOSHI KITAO, COSTAS J. SAITANIS, PIERRE SICARD, ELENA PAOLETTI, EDWARD J. CALABRESE Predicting the effect of ozone on vegetation via linear non-threshold (LNT), threshold and hormetic dose-response models. J. Science of the Total Environment, 649, 61, 2019.

37. PARK D.Y., JU Y.S., KIM J.H., AHN H., LEE C.H. Equilibrium and kinetics of nitrous oxide, oxygen and nitrogen adsorption on activated carbon and carbon molecular sieve. Separation and Purification Technology, 223, 63, 2019.

38. VIKRANT K., NA C.J., YOUNIS S.A., KIM K.H., KUMAR S. Evidence for superiority of conventional adsorbents in the sorptive removal of gaseous benzene under real-world conditions: Test of activated carbon against novel metal-organic frameworks. Journal of Cleaner Production, 235, 1090, 2019.
39. AN Y.X., FU Q., ZHANG D.H., WANG Y.Y., TANG Z.L. Performance evaluation of activated carbon with different pore sizes and functional groups for VOC adsorption by molecular simulation. Chemosphere, 227, 9, 2019.

40. ADNAN G., HÜSEYIN Y., YILDIZ K., ALI K., ADIL Ö.N., ÖZKAN K. Experimental study of butane adsorption on coconut based activated carbon for different gas concentrations, temperatures and relative humidities. Environmental technology, 2019, 1, 2019.

41. GYSEL N., WELCH W.A., CHEN C.L., DIXIT P., COCKER D.R.III. KARAVALAKIS G. Particulate matter emissions and gaseous air toxic pollutants from commercial meat cooking operations. Journal of Environmental Sciences, 65 (03), 162, 2018.

42. GYSEL N., DIXIT P., SCHMITZ D.A., ENGLING G., CHO A.K., COCKER D.R., KARAVALAKIS G. Chemical speciation, including polycyclic aromatic hydrocarbons (PAHs), and toxicity of particles emitted from meat cooking operations. The Science of the total environment, 633: 1429-1436, 2018.

43. CHEN L.T., XU X.G., DONG J.K., JIANG Y.Q. Research status and discussion of kitchen fume purification technology. Low Temperature Architecture Technology, 42 (03), 1, 2020 [In Chinese].

44. LU Y.C., OU X.Y., WANG W.G., FAN J.J., LV K.L. Fabrication of $\mathrm{TiO}_{2}$ nanofiber assembly from nanosheets ( $\mathrm{TiO}_{2}$-NFs-NSs) by electrospinning-hydrothermal method for improved photoreactivity. Chinese Journal of Catalysis, 41 (01), 236, 2020.

45. LI J.X., XU Y.Q., DING Z.Z., MAHADI A.H., ZHAO Y.F., SONG Y.F. Photocatalytic selective oxidation of benzene to phenol in water over layered double hydroxide: A thermodynamic and kinetic perspective. Chemical Engineering Journal, 388, 2020.

46. LI X.Q., ZHANG L., YANG Z.Q., HE Z.Q., WANG P., YAN Y.F., RAN J.Y. Hydrophobic modified activated carbon using PDMS for the adsorption of VOCs in humid condition. Separation and Purification Technology, 239(C).10.1016/j.seppur.2020.116517, 2020. 
